\section{Problems of tenure in Japan}

SIR-A recent Commentary (Nature $\mathbf{3 4 0 ,}$ $337 ; 1989$ ) noted that "in practice it is very difficult if not outright impossible for a foreign national to get tenure" in Japan, but discussed neither the cause of this difficulty nor how it could be ameliorated. The small number of tenured foreign faculty and the outright refusal by most universities to grant tenure to foreign faculty are particularly incongruous in the light of a recent proposal by Tokyo University "to create a science faculty which is also an internationally connected research community" (see Nature

$338,99 ; 1989)$. One of the

goals of Tokyo Univer- Rank

sity's reform plan is to Professor create an "intellectual cli- Assoc. profs.

mate that will be attractive Totals

to people from overseas".

However, the "people from overseas" will be temporary employees, mostly at the postdoctoral level, and will not be encouraged to apply for permanent positions. It is questionable whether such a plan should be characterized as "internationalization". Even on a purely pragmatic level, why does anyone think top foreign scientists will be interested in working in temporary posts in a far-away country with an unfamiliar language, where the only available career path is getting the boot?

I have been an associate professor in the department of geophysics of the faculty of science of Tokyo University since August 1984. My being hired as a tenured faculty member was due to the extraordinary efforts of Professor M. Kumazawa and his colleagues, who were committed to a policy of non-discrimination in hiring foreign faculty. My experience has been, on the whole, extremely positive from both a personal and scientific point of view.

Unfortunately, however, almost all foreign faculty members (that is, regular academic staff, excluding research associates) of Japanese national universities (including, hereafter, research institutes and joint-use institutes of Monbusho, the Ministry of Education, Science and Culture) are appointed for terms of one to ten years, with the possibility (but not a guarantee) of reappointment, whereas their Japanese colleagues are tenured. Temporary foreign faculty members, who are only nationally equal to their tenured Japanese colleagues, cannot readily become part of the Japanese scientific structure. Students, who require professorial assistance in finding employment, are unlikely to regard a temporary foreign professor as a desirable adviser. Finally, the temporary foreign staff cannot safely dispute the views of the tenured Japanese faculty who will decide on their contract renewals.

As of 1 July 1989 (statistics provided by
Monbusho) Japanese national universities employed a total of seven tenured foreign faculty members, but there were also 113 untenured foreign faculty members, with an average contract term of 2 years and 10 months. The following table summarizes the most recently available employment statistics. Note that all Japanese nationals are tenured, while almost all foreign faculty are temporary.

Japanese law was changed in 1982 to permit the employment of foreign nationals as faculty members at Japanese national

\begin{tabular}{cccc}
\multicolumn{2}{c}{$\begin{array}{c}\text { Foreign nationals } \\
\text { enured }\end{array}$} & \multicolumn{3}{c}{ Japanese nationals } \\
2 & 21 & 16,132 & 0 \\
4 & 52 & 14,276 & 0 \\
1 & 40 & 5,216 & 0 \\
7 & 113 & 35,624 & 0 \\
\hline
\end{tabular}

universities. The regulations issued by Monbusho to implement the new law state in part (my translation) that "in principle foreign faculty should be hired on a temporary basis, but, in unavoidable circumstances", the granting of tenure to foreign faculty "is not illegal". (The cognizant governing body of each university makes the final decision on what constitutes an unavoidable circumstances.) However, only five universities (Tohoku, Tokyo, Niigata, Kyushu and the National Laboratory for High Energy Physics) use this clause to employ tenured foreign faculty members.

The extremely small number of tenured foreign faculty members at Japanese national universities is thus primarily due to the rules and personnel decisions of individual national universities, rather than to Japanese law or Monbusho regulations. Why do almost all Japanese universities refuse to grant tenure to foreign faculty? Why do the handful of universities that will grant tenure to foreign faculty do so only in a small number of cases? And what, if anything, can be done to improve the situation?

First, no matter how much the administrators of Japanese national universities talk about internationalization, they have not truly grasped the notion that the development of an open university requires fully equal treatment of foreign and Japanese faculty. Second, because there is excessive concern over what would happen if a tenured foreign faculty member proves unsatisfactory, administrators prefer to retain control by hiring foreign faculty on a temporary basis. This eliminates the risks (both real and perceived) of hiring tenured foreign faculty, but also eliminates the possible benefits, which, it seems to me, far outweigh the risks. In any case, problems involving tenured Japanese nationals are by no means unknown.
Finally, it should be noted that Japanese universities are not fully open even on a national level. For example, in $1987,86.8$ per cent of the academic staff of Tokyo University were graduates of Tokyo University ( $A E R A$, No. 15, p. 15 ; 1989); the existence of such inbreeding is inconceivable at, say, any of the US universities. The failure of Japanese national universities to grant tenure to foreign faculty is only one aspect, then, of their general lack of openness, a theme I have discussed at length elsewhere (Kagaku 56, $566 ; 1986$ ). Further opening of Japanese universities to foreign faculty should also lead to a great increase in the movement of personnel between universities within Japan.

Unless the present discriminatory tenure policies are scrapped, I believe that the internationalization of Japanese higher education is doomed to fail, to the detriment of all concerned.

ROBERT J. GELleR

Faculty of Science,

Tokyo University,

Tokyo, Japan

\section{Views of the staff}

SIR-In "The museum director's view . . ." (Nature 345, 198; 1990) the director of the Natural History Museum, Dr Neil Chalmers, states "we have chosen to concentrate on those areas of taxonomic research where we already have the greatest strength. .... We have identified six such areas . . .". His use of "we" in this context could imply that the museum scientists took some corporate decision to alter the direction of research at the Natural History Museum.

Nothing could be further from the truth. The decisions were taken by a group of seven; the director, associate director and five heads of science departments, few of whom are involved in collection based research. The remainder of the museum's 300 scientists were not consulted.

Such is the sense of outrage at the museum that our senior scientists have volunteered to set up a committee, working with their trade union, IPMS, to defend science at the Natural History Museum, the museum staff are experts in the field of taxonomy, which the director is not. They are very clear about where the science priorities lie, and it is tragic that the director excluded this body of expertise from development of the corporate plan. We now face a protracted campaign to reverse the damaging decisions made in the corporate plan - a wholly avoidable situation.

\section{Institution of Professional (Branch Chair) \\ Managers and Specialists, \\ British Museum (Natural History) Branch, Cromwell Road, London SW7 5BD, UK}

PENNY WHEATCROFT 